\title{
Integrating Computers in the Classroom: Barriers and Teachers' Attitudes
}

\section{Hicham Zyad}

Hassan II University, the faculty of Letters and Humanities, Ben M'sik, Morocco, Zyadhicham@gmail.com
In recent years, several attempts have been made to reform instructional practices in the Moroccan educational system, marking the turn of the new millennium as a unique historical period pregnant with potential, aspirations and challenges. In light of the spirit of this millennium, the present paper aims to report a study that investigated secondary education teachers' attitudes towards ICT implementation in the El-Jadida province as well as the barriers that hinder the spread of ICT use for teaching purposes. Drawing on the technology acceptance model, the study used a mixed-methods approach for data collection and reputational sampling to select interview participants. In juxtaposition, the results obtained from both data sets identified several conflicts between teachers' behavioral readiness to utilize ICT in the classroom and a range of barriers that slow down the process of ICT integration. Despite teachers' positive attitudes towards ICT, it is still largely underused. The study found that this is mainly ascribable to curricular, infrastructural and logistical barriers that have to be removed to boost teachers' attitudes and encourage them to use ICT in the classroom. The study has several implications for theory, research, teacher professional development, and practice.

Keywords: education reform, ELT, ICT integration, teachers' attitudes, ICT barriers

\section{INTRODUCTION}

Today's generation of learners has changed to a great extent (Kress, 2003). Growing up in an environment teeming with all sorts of advanced technologies has enabled learners to develop multi-literacies. Instead of disregarding this new era of technological development and the various possibilities that this development has opened up, educators, education policy makers, teachers and the civil society as a whole need to take advantage of this situation to create a technology-enhanced language learning environment. The call for more ICT integration into mainstream education becomes more pressing when the tools, options and benefits of technology are foregrounded. For example, Internet-based activities can give learners access to authentic materials that they can use to develop their language skills more effectively (Zhang \& Barber, 2008). Of interest is the fact that technology has eradicated the constraints of time and space so that learners can communicate and engage in collaborative learning with peers from around the world. Besides, ICT enables language learners to tailor the learning process to their personal needs. They become autonomous in the sense that they set and define 
their own objectives, use authentic materials effectively, delimit the time for learning, assess the results and redirect the learning process if necessary.

\section{CONTEXT}

A central aspect of the educational reform in Morocco is the gradual integration of ICT into teaching practices. This reform was inaugurated by the National Charter of Education and Training (Ministry of National Education in Morocco, 1999). In article 10 , the Charter encourages the integration of ICT in education and promotes the creation of computer facilities in schools with a view of paving the way for distance education and learning. A national action plan was drafted in 1998 and finalized in May 1999 in the midst of strong political will and the collaboration of a selected committee of business leaders and representatives of the civil society (Hamdy, 2007). With all this in mind, it is useful at this point in time to conduct research seeking to evaluate the progress that has been made in ICT integration into secondary education through an exploration of teachers' attitudes. Such exploration aims to see whether or not the initiatives and programs launched so far have had the desirables effects of supporting teachers' positive attitudes reported in previous research (Erguig, 2009) and of changing for the better those teachers' attitudes that were skeptical about the utility of ICT for classroom purposes. The study also attempts to gauge the extent to which the barriers that have been reported in previous studies have successfully been surmounted (Alj \& Benjelloun 2013; Ouardaoui et al, 2012).

\section{Objectives}

Therefore, one of the objectives of the paper is to explore the barriers that discourage the EFL teachers in the El-Jadida province from utilizing ICT for pedagogical purposes. Such exploration can be useful in that it helps education stakeholders in Morocco to evaluate the impact of the successive ICT-related initiatives on classroom practices. Another objective is to assess teachers' attitudes towards ICT implementation in the classroom. Finally, the paper aims to ascertain whether or not there are any statistically significant relationships between attitude and teachers' characteristics such as gender, age, teaching experience, geographical location, ICT training and the duration of the training.

\section{Research Questions}

The study set out to answer the following research questions:

i. What are the barriers that prevent EFL secondary education teachers from implementing ICT in their teaching practices in the province of El-Jadida?

ii. What are the attitudes of the teachers towards ICT integration in education?

iii. Are there any relationships between teachers' attitudes and variables such as gender, age, teaching experience, geographical location, ICT training and the duration of the training?

\section{REVIEW OF THE LITERATURE}

\section{ICT-related Barriers}

Researchers and educators have offered different categories to classify the factors that discourage teachers from using ICT in the classroom. An example of such classifications 
is the one offered by Jimoyiannis (2008) including personal, school-related, technical and pedagogical factors. By personal barriers, reference is made to those personal qualities and choices that deter teachers from integrating ICT in their instructional practices (Jimoyiannis, 2008). For instance, it has been revealed that female teachers show less confidence in using computers and they display greater computer anxiety than males (Cartelli \& Palma, 2008). Some studies reported that gender differences towards computer use are dwindling (Shapka \& Ferrari, 2003), whereas others showed that male teachers were more positive about ICT than females, being either undecided or negative (Jimoyiannis \& Komis, 2006). Age differences have also been reported to constitute a hindrance to the implementation of ICT in teaching (El-saadani, 2013).

Technical concerns are also of importance in the success or failure of ICT integration into the educational environment (Jimoyiannis, 2008). Among such concerns are resources availability, time constraints and educational software. The shortage of computers and educational software may have serious repercussions on the potential use of ICT as an aid in the teaching process (El-Ouidadi et al., 2011). Research conducted with a view of assessing the availability of resources and how this can affect teachers' perceptions and attitudes towards ICT indicated that good practices were reported in schools that include high-quality ICT resources (Mumtaz, 2000). By contrast, other studies showed that despite the availability of resources, they remained underused (Cuban, 2001).

There is a general agreement among teachers that ICT is a valuable addition to their teaching methodology and they have confidence in its capacity to enhance and facilitate the learning process (Jimoyiannis, 2008). Despite this positive appraisal of ICT, Waite (2000) reported that teachers do not subscribe to the view that calls for the extensive use of ICT in education and there are some teachers who doubt the ability of ICT to enhance learning outcomes (as cited in Cartelli \& Palma, 2008). Many schools, colleges and departments of education were reported to show resistance in embracing technological innovations within their educational plans and policies (Stetson \& Bagwell, 1999). Sugar, Crawley, and Fine (2004) concluded that the decision to use ICT is not influenced by other people and occurs irrespectively depending on the presence or absence of resources and barriers in the school or in its environment.

Having effectively addressed the above mentioned barriers (personal, school-related and technical), it remains for teachers to utilize ICT within a framework that allows for learner autonomy, collaborative leaning, experiential learning, problem-solving, higher order thinking skills and life-long learning. Becker (2001) argued that computers serve as a "valuable and well-functioning instructional tool" (p. 29) in schools and classrooms provided that teachers have accessibility, are pedagogically prepared, have more leeway in the curriculum and nurture beliefs in harmony with constructivist principles. Ertmer (2010) clarified that ICT is expanding ever more increasingly in the USA. However, he maintained that, despite the expansion, the majority of teachers still use ICT for lowlevel tasks such as word processing and surfing the Internet. 


\begin{abstract}
Attitudes towards ICT integration
Albirini (2006) found that teachers have positive attitudes towards ICT in education. For instance, the majority of the participants regarded computers as a strong educational tool that can bring about significant improvements to schools and classrooms. The findings suggested that teachers were in the decision-making process and that they had already gone through the knowledge and persuasion stages. The study also revealed a very strong relationship between teachers' attitudes towards ICT in education and their perception of computer attributes.
\end{abstract}

Jimoyiannis and Komis (2006) conducted an exploratory study probing secondary education teachers' attitudes toward and beliefs about ICT integration. They found that roughly $25 \%$ of the participants used ICT for preparation and communication purposes rather than for instruction delivery or assigning students ICT-based tasks. The researchers claimed that there was a noticeable increase in teachers' attitudes toward ICT utilization for pedagogical reasons in Greece. Moreover, despite teachers' lack of the necessary computer skills, they held positive attitudes toward the potential of ICT in improving teaching practices. The need to convince teachers for the utility of ICT in education, the insecurity about success in ICT training and the fear that students might be more knowledgeable about computers were additional factors that shaped teachers' attitudes in the study.

In the Moroccan educational context, Ouardaoui et al (2012) investigated how ICTbased education may generate a better motivation and performance in science students (Chemistry-Physics, Mathematics, and Life-Earth sciences). The results led to the rejection of the null-hypothesis as the experimental group outperformed the control group. The analysis concluded that ICT had a positive impact on students' learning and performance in Chemistry-Physics for the 8th and 9th grades in one institution and 7th and 9th grades in the other. The observations showed that ICT-based activities caused an increase in students' motivation for learning.

In Erguig (2009), there was a consensus among all the teachers that ICT is useful as it helps students to acquire a variety of different skills in Moroccan universities. Some teachers expressed reservations as to the usefulness of ICT with regard to the nature of the subject being taught. $2 / 3$ of the teachers were unsure whether ICT can foster any better learning and recommended that there should be a further research in this area. The study also reported that ICT can be crucial in breaking the constraints of time and place imposed on traditional learning. This means that learning by means of technology may occur in a variety of different contexts other than the classroom.

\title{
METHOD
}

\section{Participants' demographics}

The data revealed that the number of male teachers (33) is greater than female teachers (23). The reason for this asymmetry is attributable to the fact the study included all the teachers working in the province of El-Jadida. As regards age, the largest age group for all respondents was between 30 and $39(21,37.5 \%)$ whereas the smallest age group was 
between 40 and $49(10,17.9 \%)$. Intermediate between these two age groups are respondents whose age ranges between 20 and $29(12,21.4 \%)$ and those aged between 50 and $59(13,23.2 \%)$.

The majority of teachers $(n=18,32.1 \%)$ in the sample have a teaching experience that ranges from 6 to 10 years with a minority of teachers $(n=8,14.3 \%)$ whose teaching experience ranges either between 16 and 20 or over 20 years. The greatest number of male teachers $(\mathrm{n}=12,36.4 \%)$ is situated within a range of 16 to 20 years while the lowest number $(n=4,12.1 \%)$ has a teaching experience ranging either from 1 to 5 or over 20 years. By contrast, female teachers located in the range between 1 to 5 years of teaching experience constitute the majority $(n=8,34.8 \%)$ with no female teachers between 16 to 20 years. Regarding the location of the schools where the teachers work, it was indicated that $23(41.1 \%)$ teachers work in urban areas with female teachers representing $52.2 \%$ while $24(42.9 \%)$ teachers work in rural areas in which male teachers constitute the majority $(n=17,51.5 \%)$. The rest of the teachers $(n=9,16.1 \%)$ work in suburban locations.

As for teachers' computer training, $39(69.6 \%)$ teachers reported that they had participated in a training program with $21(63.6 \%)$ male teachers and $18(78.3 \%)$ female teachers. Concerning training duration, table 5 indicates that $13(61.9 \%)$ male teachers had a training that lasted for either three months or over three months. With the least rate of participation in computer training programs, $6(33.3 \%)$ female teachers reported that they had had a training program whose duration was three months or over months.

\section{Instruments}

The present study used a questionnaire and a semi-structured interview. The questionnaire was constructed to elicit information regarding the three research questions that the study set out to answer. On the basis of five-point Likert scales, the participants were required to state their level of agreement on the items presented. As regards the semi-structured interview, it consisted of several questions attempting to obtain data on the three research questions driving the present study. As for sampling, the questionnaire respondents were all the EFL secondary education teachers working in the El-Jadida province $(n=56)$ while the interview participants $(n=4)$ were selected on the basis of reputational sampling (Denscombe, 2010). Reputational sampling was used to select only those teachers who had a reputation of implementing ICT in their classrooms. Both data collection instruments were piloted to resolve issues of layout, wording of the items, readability, clarity and acoustics. The rationale motivating the use of two instruments for data collection is for methodological triangulation; that is, the results obtained from one source can be cross-examined by results obtained from another source of data collection (Denscombe, 2010; Kothari, 2004). To resolve issues of confidentiality, the researcher used codes in the questionnaire and pseudonyms in the interview to conceal the respondents' identities.

\section{Procedures}

The study used both descriptive and inferential statistics to organize and analyze the quantitative data. As for descriptive statistics, the study used graphs and tables to 
present the results in a neatly organized manner. The inferential statistic employed in the study was the Spearman correlation coefficient. This statistic was used to evaluate the relationships between attitude and teachers' characteristics. The Spearman correlation statistic tells whether a relationship holds between two or more variables and it also offers a figure indicating the strength of the relationship (Kothari, 2004). Concerning the analysis of qualitative data, the researcher used categorization process, and subcategorization to analyze the data and uncover emerging themes (Denscombe, 2010).

\section{RESULTS}

\section{ICT-related Barriers}

The results showed that almost all the barriers reported in previous research are still in effect in the province of El-Jadida. The poor quality of the school equipment, lack of communities of practice and lack of collaboration among teachers were reported to be on top of all the barriers that impede ICT use in the classroom by female teachers $(100 \%)$. The results also showed that male teachers seemed to be more prepared to be engaged in collaborative work as only $36 \%$ male respondents said that the lack of communities of practice is a barrier to ICT integration and $47 \%$ indicated that the lack of collaboration constituted a hindrance to ICT implementation.

The barrier that received the greatest percentage from both male $(100 \%)$ and female (95\%) teachers is the lack of incentives. $100 \%$ female respondents and $97 \%$ male respondents roughly expressed unanimity that concern with curriculum coverage is a major impediment that prevents them from fully integrating ICT in their classroom practices. There is almost general consensus among both female (100\%) and male (90.9\%) teachers that concern with joint local and national examinations represents a significant barrier to the use of ICT in the classroom. More than two thirds of female participants rated the lack of technical training as the least serious barrier to ICT integration whereas $84.8 \%$ male participants reported that the lack of time is the least important hurdle to the use of technology in the classroom.

According to the qualitative data, all the teachers agreed that a classroom crowded with students and with no ICT equipment does not encourage the teacher to plan lessons based on ICT. When asked about how class size can be viewed as a barrier to ICT use in the classroom, Fatima replied that "a class composed of 45 to 50 students must take you much time to control and manage without ICT, let alone when you want to try something new". The other major barrier that was highlighted by all the interviewees was the concern to cover the syllabus within the time frame allocated by the authorities concerned. Two participants, Ali and Fatima, stressed that they were all the time "haunted with the nightmare" of running out of time without transferring the content of the syllabus to their students.

Moreover, the lack of incentives was viewed as a serious barrier that prevents teachers from using innovative ways of teaching and in particular ICT as a learning tool and medium. "People expect you to be innovative without offering you anything in the way of encouragement, be it material or symbolic", Ali said sarcastically. As for computer literacy, all the teachers selected for the interview had had ICT training. The focus of the 
training, the participants reported, was on the technical aspects of using computers and developing teachers' confidence in the use of technology at the expense of pedagogical relevance.

\section{Attitude and teachers' characteristics}

\section{The Affective Component of Attitude}

Generally speaking, the respondents had positive feelings about ICT (mean $=4.32$, Std. $\mathrm{D}=.47$ ). All male participants express happiness that there the number of computers is increasing these days while $91 \%$ female participants stated that the increasing numbers of computers makes them happy. $16.1 \%$ male teachers and 37.9 female teachers reported that computers make them nervous. 28.5 male teachers and 11.9 female teachers reported that they like to take part in computer literacy training programs.

\section{The Cognitive Component of Attitude}

The cognitive component of attitude was divided into two subcomponents: perceived ease of use and perceived usefulness, both of which were generally positive (means = $4.1 ; 4.2$, Std. Ds $=.38 ; .42$ respectively). There was a $97 \%$ agreement among male teachers that computers have several benefits for students and are a fast and efficient means of getting information. Computers' potential to enhance teachers' job performance and the perception that they are useful were slightly above $90 \%$.

A strikingly low percentage was obtained on the issue of teachers' competence to use ICT to achieve important learning outcomes (males, $6.1 \%$; females, $13.0 \%$ ). However, a moderate level of agreement (males, $66.7 \%$, females, $65.2 \%$ ) went to the respondents' ability to use computers from a technical perspective. As for the ability to solve computer breakdown, there was a slightly below average percentage (males, $48.5 \%$ ) of participants being unable to solve computer breakdown while $39.1 \%$ of female teachers having difficulty with computer breakdown repair. Besides, $63.6 \%$ male teachers and $69.6 \%$ female teachers reported that they did not know how to blend ICT with EFL teaching.

\section{The Behavioural Component of Attitude}

Similarly, it seems that the respondents had a behavioral readiness to use computers in the classroom provided a number of conditions were satisfied. The preference to work by hand instead of using computers ranged from $63.6 \%$ to $69.6 \%$. A high proportion of teachers claimed readiness to actually use ICT in the classroom if the quality of the school equipment improved. About one third of the participants disagreed that they would avoid computers as much as possible. General agreement appears to be among the teachers (males, 90.9\%; females, 100\%) that they would use ICT if they were convinced that it had an added value in the learning process. The table below summarizes the means and standard deviations for each of the three components of attitude: 
Table 1: Attitude towards ICT integration in education

\begin{tabular}{lcccc}
\hline & \multicolumn{2}{c}{ Male } & \multicolumn{2}{c}{ Female } \\
\hline & $\begin{array}{c}\text { Strongly } \\
\text { Agree \& Agree }\end{array}$ & \multicolumn{2}{c}{$\begin{array}{c}\text { Strongly } \\
\text { agree \& agree }\end{array}$} \\
\hline Mean & $\begin{array}{c}\text { Standard } \\
\text { Deviation }\end{array}$ & Mean & $\begin{array}{c}\text { Standard } \\
\text { Deviation }\end{array}$ \\
\hline The affective component & 4.32 & .47 & 4.31 & .44 \\
\hline The cognitive component & 4.32 & .44 & 3.95 & .36 \\
\hline The behavioural component & 4.34 & .45 & 4.16 & .32 \\
\hline
\end{tabular}

The qualitative data supported the findings from the questionnaire by offering explanations to the positive attitudes towards ICT. Without exception, the four participants expressed a positive attitude towards ICT implementation in classroom practices. Ibrahim stated that "surely, ICT can do a lot of things to all of us at the personal, administrative and educational levels". In the same vein, Fatima promptly replied that "it goes without saying. Since ICT is a reflection of the genius of today's world, it must be made an everyday scene in the educational context. Attention should be directed at the participants use of words and expressions such as "sure, surely and it goes without saying", which are suggestive of the deep belief that teachers seem to have about the potential of ICT in teaching.

The reasons that the participants provided to justify such positive attitudes can be categorized into personal and educational. At the personal level, the teachers suggested that ICT was pivotal in granting opportunities for self-development and professional growth. Additionally, they all pointed out that ICT opened up easy access to valuable information, which could have taken ages for past generations to obtain. Fatima was unequivocal in this regard when she said that "the wealth of information that the internet so generously makes accessible to everyone, everywhere and at any time makes teaching far much easier to perform". She made it clear that her life could have been tougher and monotonous without the internet as she lives in the countryside. At the educational level, there was agreement among the teachers that the positive attitude they had about ICT in education emanated from the confidence they had in the capacity of ICT in improving the quality of the teaching/learning process. The teachers believed that students could achieve autonomy in learning if they were provided with guidance and orientation from their teachers. Moreover, the interviewees seemed to suggest that the affordances of the internet would empower students with life-long learning and endow them with skills that would render them resourceful and insightful 21 st century citizens.

\section{Correlations: Attitude and Teachers' Characteristics}

Data analysis revealed that there were statistically significant correlations between attitude and teachers' characteristics as table 2 shows:

Table 2: Correlations between attitude and teachers' characteristics

\begin{tabular}{lccccc}
\hline & Age & $\begin{array}{c}\text { Teaching } \\
\text { experience }\end{array}$ & $\begin{array}{c}\text { School } \\
\text { Location }\end{array}$ & $\begin{array}{c}\text { ICT } \\
\text { training }\end{array}$ & $\begin{array}{c}\text { Duration } \\
\text { of training }\end{array}$ \\
\hline Affective component & -.565 & -.496 & -.424 & -.421 & .388 \\
\hline Cognitive component & -.586 & -.535 & -.507 & -.508 & .484 \\
\hline Behavioural component & -.530 & -.514 & -.366 & -.459 & .475 \\
\hline
\end{tabular}


The Spearman correlation coefficient values resulting from the relationship between the affective component of attitude and the teachers' characteristics were all statistically significant ranging from -.565 to .388 . Stronger values were obtained from the correlation between the cognitive component and the teachers' characteristics ranging from -.586 to -.484 . As regards the behavioral component, its correlations with the teachers' characteristics ranged from -.530 to -.366 . The only relationship that obtained a weak value was the one between the behavioral component of attitude and school location $(\mathrm{r}=-.366)$. All the correlations were negative except for the correlation between attitude and training duration.

\section{DISCUSSION}

\section{ICT-Related Barriers}

The quantitative data pointed to the fact that the greatest majority of the barriers reported in previous studies still persist in the province of El-Jadida to a considerable degree. This finding seems to be in accord with other studies carried out in different places in the world (Albirini, 2006; Bradley \& Russel, 2000; Erguig, 2006). The fact that there was a striking difference between the perceptions of male and female teachers about the lack of communities of practice and collaboration among teachers may be interpreted as suggestive of the fact that there might be more collaboration among male teachers than female teachers. However, there was a consensus among the participants that the lack of coordination with the administration usually spoils their plans to engage their students in technology-based activities. The results pertaining to the three factors are supported by research conducted in other educational contexts (Jimoyiannis \& Komis, 2007; Yildirim, 2000). These studies, among others, showed that a school culture that promotes individualism and condemns teamwork is hardly appropriate for ICT integration. It is almost unthinkable to launch training programs for all the teaching staff of a given country, especially as the field of technology is changing with an extremely fast pace. For this reason previous studies recommended having an ICT coordinator or mentor who can transfer ICT skills and the latest developments in the field to his or her colleagues (Kumar \& Kumar, 2003).

A high proportion of teachers in the study reported that the lack of time, concern with syllabus coverage and concern with national examinations were crucial hurdles that caused a low rate of ICT usage in the teaching profession. This is consistent with the British Educational Communications and Technology Agency's (henceforth, Becta) report showing that teachers had to grapple with multiple tasks including teaching, coordinating with parents and attending staff meetings, which left them with little time available for experimenting with ICT (Becta, 2004). The high percentage of teachers who rated students' demotivation as a noteworthy obstacle is supported by evidence from other studies as well. To exemplify, Becta (2004) cited Preston et al (1999) reporting "on comments made about technical problems resulting in the demotivation of students". This means that the incident of a technical breakdown may cause the students to feel demotivated about ICT activities. Large class size may be deemed a big problem when the classroom is equipped with a number of computers so that small groups of students would have to cluster around one computer. 
Identically, the quantitative and qualitative results suggested that most of the macrolevel barriers that emerged in previous studies were still widespread in the educational system in Morocco. A top-down approach to ICT integration appears to call to mind the issue of how to encourage the teacher as a key player to contribute to the change effort. An extremely high proportion of teacher participants considered the lack of incentives as a contributor to the slowdown of ICT implementation in education (males, 100\%; females, 95.7\%). It seems that the participants had a vivid understanding of the importance of technical and pedagogical training reflected in the high proportion of teachers who said that there was a lack in this respect. The interview data drew attention to the lack in the practical side of training programs. It was indicated that the focus in the training programs had been on the technicalities germane to computer literacy without adequate reference to how this literacy interacts with pedagogy in more practical terms.

\section{Attitudes towards ICT Integration}

In general, the respondents had a positive attitude towards ICT integration in education. The means for the three components of attitude surpassed the average threshold (affective, $\mu=3.91$; cognitive, $\mu=3.65$; and behavioral, $\mu=4.07$ ) indicating a strong positive attitude about ICT implementation for pedagogical purposes. Not only did the data from the interview reiterated the positive attitude reported in the questionnaire but it also provided explanations for why teachers held such an attitude.

Previous research conducted in other educational contexts also reported positive values for the affective domain towards ICT integration in education (Albirini, 2006; Erguig, 2009). It was seen from the interview that despite not having a clear understanding of how ICT can bring about significant changes in education, the interviewees stated that they had a liking for computers (Albirini, 2006). The positive values for perceived ease of use and usefulness are consistent with results from studies exploring the perceptions of teachers about the usefulness of computers in education (Albirini, 2006; Rastogi \& Malhotra, 2013). However, El-Ouidadi et al (2011) found that a third of the respondents were skeptical about the potential of technology in education and hence they used it only for personal and preparation purposes. Apparently, the teachers had a strong willingness to incorporate of ICT in education, which was reflected in the high value for behavioral intention to use technology in the classroom $(\mu=4.07)$. The survey conducted by Albirini (2006) drew the same conclusion about EFL teachers' readiness to use technology in Syria.

\section{Attitude and Teachers' Characteristics}

The current study found that there was no relationship between attitude and gender $(\mathrm{r}=$ $.12, \mathrm{p}<.05)$. Albirini (2006) came to the same conclusion regarding the relationship between gender and attitude. This may be interpreted as a reflection of the democratization process of ICT with men and women having equal chances of accessing the computer and the internet and hence allowing them to develop positive attitudes towards ICT. Besides, the study found a statistically positive relationship between attitude and age. The relationship was to the effect that the younger the teacher, the more likely it would be that he or she would use technology for teaching. Support for 
this result comes from a study conducted by El-saadani (2013) demonstrating a moderate positive relationship between age and attitude.

The correlation between school location and attitude was significant at an alpha level of $\mathrm{p}<.05(\mathrm{r}=-.467)$. A viable interpretation of this relationship could be that the situation in rural areas is worse in terms of infrastructure and its impact on students' cooperation with the teacher in case he or she used ICT as a component of his teaching methodology. With an alpha level at $\mathrm{p}<.05$ and a Spearman correlation coefficient at -.526 , the relationship between teaching experience and attitude can be described as substantial. El-saadani (2013) found the same pattern between attitude and teaching experience in the Egyptian context. The correlational statistical test showed that there was a significant negative moderate relationship between training and attitude towards ICT $(r=-.476, \mathrm{p}<$ .05). This suggests that the teachers having training in ICT had a tendency towards nurturing positive attitudes about technology in education. Experimental studies discovered that there was a boost in the participants' attitudes as they became more confident with technology (Ouardaoui et al (2012). When the Spearman correlation coefficient of all the items on attitude were averaged, they yielded a moderate positive correlation between attitude and training duration $(r=.456)$, with the alpha level set at $\mathrm{p}<.05$. This suggests that the respondents who had a longer training duration would have a more positive attitude towards ICT than those who had shorter or no training at all (Jimoyiannis, 2008).

\section{IMPLICATIONS}

A common denominator among the quantitative and qualitative data was the lack of technical and pedagogical training. This area needs to be dealt with insightfully by increasing the number of training programs and decreeing the necessity for making them a yearly event. Measures must be taken to make attendance to training programs and workshops mandatory so that all the teaching staff can benefit from them on an equal footing. Identically, a permanent ICT coordinator or mentor needs to be made available to transfer the relevant knowledge and expertise to colleagues and to intervene in case of technical breakdown. A balance seems to be required between technology and pedagogy when planning training programs. Similarly, the interview uncovered the need for offering teachers practical models of the blend between technology and pedagogy so that the teachers can assess in more concrete ways how the technological, pedagogical knowledge can be a powerful assortment in generating quality learning.

The lack of ICT equipment and the poor quality of such equipment when available were shown to be unavoidable issues that must be surmounted with a view to make technology an ordinary scene of Moroccan classrooms. Accordingly, policy masterminds and decision makers need to allocate funding to equipping schools with both hardware (a computer per one or two students, head projectors, and broadband internet connection) and software (educational programs and learning systems). Besides, calls must be made for ICT to be an inbuilt component of the Moroccan curriculum so that it would not be approached by the teachers as an extra, supplementary element in their teaching methodology. This is reminiscent of Albirini's comment that "equal innovativeness in structural, pedagogical and curriculum approaches" (2006, p. 385) is compulsory for further ICT integration in the educational system. 


\section{CONCLUSION}

This paper has come at a time when there is a need for an exploratory study that aims to gauge the extent to which ICT integration in education has been successful in gaining a strong foothold in the Moroccan educational system. The paper began by probing the barriers that impede ICT use in the classroom. The results revealed that most of the barriers reported in previous research still continue to disrupt teachers' attempts at integrating technology in their instructional plans. Subsequently, the study addressed teachers' attitudes towards ICT use for pedagogical purposes. It was found that teachers' attitudes towards ICT are still as positive as they used to be in past research. As regards the presence or absence of relationships between attitude and teachers' characteristics, it was shown that except for gender, all the factors statistically tested had a relationship with attitude.

\section{REFERENCES}

Albirini, A. (2006). Teachers' attitudes toward information and communication technologies: The case of Syrian EFL teachers. Computers \& Education, 47(4), 373398.

Alj, O., \& Benjelloun, N. (2013). Intégration des TIC dans l'enseignement des sciences physiques au Maroc dans le cadre du programme GENIE: Difficultés et obstacles. International Journal of Technologies in Higher Education, 10(2), 49-65.

Becker, H. J. (2001). How are teachers using computers in instruction? Paper presented at the Annual Meeting of the American Educational Researchers Association, Seattle, USA. https://www.stcloudstate.edu/

British Educational Communications and Technology Agency. (2004). A review of the research literature on barriers to the uptake of ICT by teachers. Retrieved 2 18, 2014, from http://dera.ioe.ac.uk/1603/1/becta_2004_barrierstouptake_litrev.pdf

Cartelli, A., \& Palma, M. (2008). Encyclopedia of information and communication technology. New York: Information Science Reference.

Cuban, L. (2001). Oversold and underused: Computers in the classroom. Cambridge, MA: Harvard University Press.

Denscombe, M. (2010). The good research guide for small-scale social research projects. Berkshire: Open University Press.

El-Ouidadi et al., (2011). Analyse d'attitudes et de besoins d'enseignants marocains en TICE: Cas de l'académie (AREF) des Fes-Boulmane, Maroc. Radisma, 7, 1-15.

El-saadani, M. (2013). Exploring the relationship between teaching staff age and their attitude towards ICT. International Journal of Instruction, 6(1), 215-226.

Erguig, R. (2009). The use of information technologies and audiovisual media in ELT: The department of English in El-jadida, Morocco, as a case study. Porto Linguarum, 11, 115-128.

Ertmer, P. (2010). Teacher technology change: how knowledge, confidence, beliefs and culture intersect. Journal of Research on Technology in Education, 42(3), 255-284. 
Hamdy, A. (2007). ICT in education in Morocco. Retrieved 2 13, 2014, from http//:www.infodev.org/.

Jimoyiannis, A. (2008). Factors determining teachers' beliefs and perceptions of ICT in education. In A. Cartelli, \& M. Palma, Encyclopaedia of information communication technology (Vol. 1, pp. 321-334). New York: Information Science Reference.

Jimoyiannis, A., \& Komis, V. (2006). Exploring secondary education teachers' attitudes and beliefs towards ICT in education. THEMES in Education, 7(2), 181-204.

Kothari, C. R. (2004). Research methodology: Methods and techniques. New Delhi: New Age International Publishers.

Kress, G. (2003). Literacy in the new media age. New York: Routledge.

Ministry of National Education in Morocco. (1999). National Charter of Education and Training. Retrieved 2 14, 2014, from http://www.cse.org.ma/ar/admin_files/

ressources/Charte-men_ar.pdf

Mumtaz, S. (2000). Factors affecting teachers' use of information and communication technology: A review of the literature. Journal of Information Technology for Teacher Education, 9(3), 319-341.

Ouardaoui et al., (2012). ICT integration into chemistry-physics classes in middle schools through a participatory pilot project approach. Procedia: Social and Behavioural Sciences, 55, 232-238.

Shapka, J. D., \& Ferrari, M. (2003). Computer-related attitudes and actions of teacher candidates. Computers in Human Behaviour, 19(3), 319-334.

Stetson, R., \& Bagwell, T. (1999). Technology and teacher preparation: An oxymoron? Journal of Technology and Teacher Education, 7(2), 145-152.

Sugar et al., (2004). Examining teachers' decisions to adopt new technology. Educational Technology and Society, 7(4), 201-213.

Zhang, F., \& Barber, B. (2008). Computer-enhanced language acquisition and learning. New York: Information Science Reference.

\section{Turkish Abstract}

Tutum Perspektfileri: Sınıfta İki Dil Entegreli Uygulamaya Bir Etmen: Engeller ve Öğretmenlerin Tutumları

Son yıllarda zorluklara ve ilhamlara gebe olan eşsiz bir tarihi period olarak yeni milenyum dönüşü olarak Fas eğitim sisteminde öğretim uygulamalarında reform için bazı girişimler yapılmıştır. Dönemin ruhunun 1şı̆̆ında, bu çalışma öğretim amaçlı ICT kullanımının yaygınlaşmasına engellerin yanında El-jadida bölgesinde ICT uygulamalarına karşı ortaöğretim öğretmenlerinin tutumlarını araştırmayı amaçlamaktadır. Teknoloji kabul modeli üzerinden, veri toplama için karma yöntem ve görüşme katılımcılarının seçilmesi için reputasyonel örnekleme kullanılmıştır. Yanyana olarak, her iki veri setinden elde edilen sonuçlar sınıfta ICT için öğretmenlerin davranışsal hazır olmalarında bazı uyuşmazlıklar ve süreci yavaşlatan bir takım engeller ortaya çıkardı. ICT’ye karşı olan pozitif tutumlara rağmen, hala kullanılmamaktadır. Bu çalışma bunun müfredata yüklenilebilir olduğunu, sınıfta ICT kullanımı için öğretmenlerin 
tutumlarını artıracak ve cesaretlendirecek yapısal ve lojistik engeller kaldırılması gerektiğini ortaya çıkarmıştır. Çalışma teori, araştırma, profesyonel gelişim ve uygulama için bazı öneriler sunmuştur.

Anahtar Kelimeler: eğitim reform, ELT, ICT entegrasyonu, öğretmen tutumu, ICT engelleri

\section{French Abstract}

Perspectives D'attitude: un Facteur à Mise en œuvre d'une Langue Double Intégrant Ordinateurs dans la Salle de classe: Barrières et les Attitudes de Professeurs

Ces dernières années, plusieurs tentatives ont été faites pour reformer des pratiques d'instruction dans le système éducatif marocain, marquant le tour du nouveau millénaire comme une période historique unique enceinte avec le potentiel, des aspirations et des défis. À la lumière de l'esprit de ce millénaire, le papier présent a pour but de faire un rapport sur une étude qui a examiné les attitudes des professeurs d'enseignement secondaire vers la mise en œuvre ICT dans la province(le domaine) El-Jadida aussi bien que les barrières qui gênent la diffusion d'utilisation d'ICT pour des buts pédagogiques. En attirant le modèle technologique d'acceptation, l'étude a utilisé une approche de méthodes mixtes pour la collecte de données et l'échantillonnage de réputation pour choisir des participants d'entretien. Dans la juxtaposition, les résultats obtenus des deux ensembles de données ont identifié plusieurs conflits entre l'empressement comportemental des professeurs d'utiliser ICT dans la salle de classe et une gamme de barrières qui ralentissent le processus d'intégration d'ICT. Malgré les attitudes positives des professeurs vers ICT, il est toujours en grande partie sous-utilisé. L'étude a constaté que c'est principalement attribuable aux barrières scolaires, infrastructurelles et logistiques qui doivent être enlevées pour stimuler les attitudes des professeurs et les encourager à utiliser ICT dans la salle de classe. L'étude a plusieurs implications pour la théorie, la recherche, le développement de professionnel de professeur et la pratique.

Mots Clés: réforme d'éducation, ELT, intégration d'ICT, les attitudes de professeurs, barrières ICT

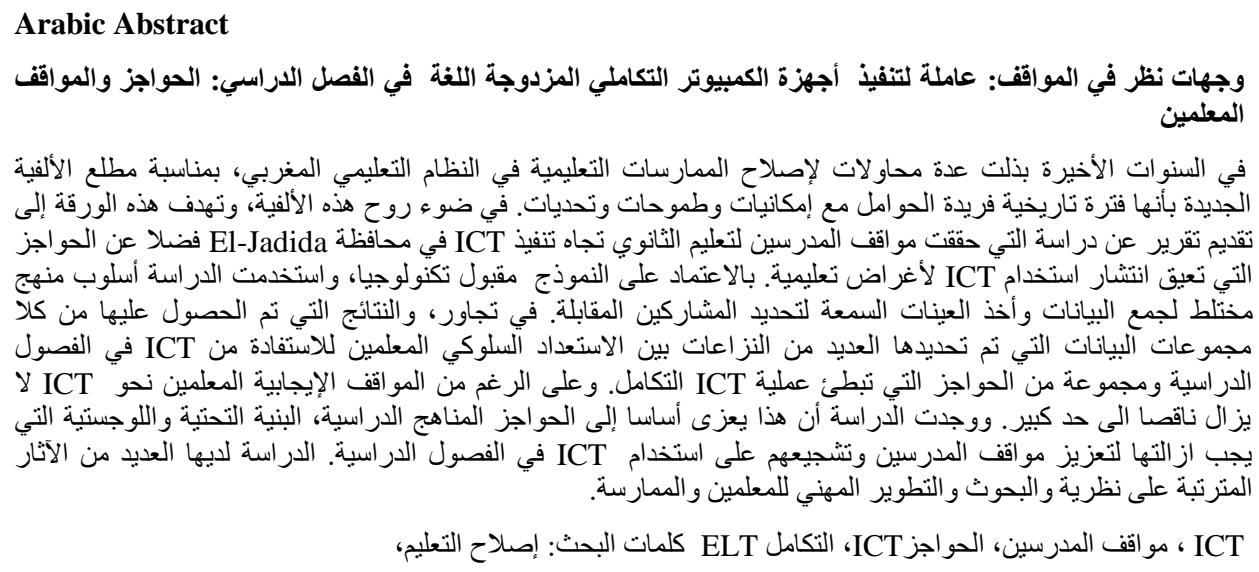

